\title{
A GESTÃO DAS INSTITUIÇÕES DE EDUCAÇÃO INFANTIL DE O A 3 ANOS NUMA PERSPECTIVA FOUCAULTIANA
}

\author{
Maria das Graças Fernandes de Amorim dos Reis
}

\begin{abstract}
Resumo
O presente texto nos remete à gestão da educação infantil nas instituições denominadas Creches que atendem a faixa etária de o a 3 anos. Considerando que a passagem destas para a responsabilidade da Educação, a partir da LDB n ${ }^{\circ} 9.394 / 96$, suscitou, entre outros, o debate "assistencialismo versus educativo" em relação ao atendimento das crianças pequenas. Visualizou-se, por meio da pesquisa, a caracterização da gestão na busca de superação da referida contraposição, na medida em que tal processo inaugurou outras relações a partir da produção de saberes e práticas no interior destas instituições, agora no tempo da educação.
\end{abstract}

Palavras-chave: Gestão Educacional, Educação Infantil, Creches.

\section{MANAGEMENT OF INSTITUTIONS OF EDUCATION OF CHILDREN O TO 3 YEARS IN A FOUCAULTIAN PERSPECTIVE}

\begin{abstract}
This text refers to the management of early childhood education in the institutions called Creches that serve the age group o to 3 years. Whereas their transition to the responsibility of education from the LDB, n. 9.394/96, was raised among others, the debate "welfare versus education' in relation to the care of young children, we found that by searching the characterization of management in the pursuit of overcoming such opposition, to the extent this process has opened other relations from the production of knowledge and practice within these institutions, now in the time of education.
\end{abstract}

Keywords: Educational administration, Early Childhood Education, daycare 


\section{Introdução}

O presente artigo apresenta-se como parte de um estudo diagnóstico sobre a gestão das instituições de educação infantil, denominadas Creches do Município de São Carlos-SP, realizado no curso de doutorado e concluído em 2007. Objetiva apresentar dentre muitos, alguns elementos que a gestão traz para discussão do trabalho na Creche, após sua passagem da Assistência Social para a Educação, em 1999, focando a produção de saberes e práticas no interior dessa instituição de educação infantil a partir de então.

Atualmente, na Lei de Diretrizes e Bases da Educação, LDB nº 9.394/ 96 o termo Creche designa as instituições de educação infantil que atendem à faixa etária de 0 a 3 anos e Pré-escola para denominar aquelas que atendem crianças de 4 a 6 anos (ou 4 e 5 anos a partir da organização do ensino fundamental em nove anos ${ }^{1}$ ). Mas, ao longo da história, ambas as instituições receberam tratamento diferenciado no que se refere ao tipo. de instituição e a classe social atendida.

Segundo Abramowicz (2006), em geral, a Pré-escola era designada como instituição de uma classe com melhores possibilidades econômicas e sociais e as Creches como instituições destinadas ao atendimento de crianças pobres e filhos de mães trabalhadoras.

Essa associação da Creche à pobreza e às classes populares fez com que ela fosse constituída ao longo do tempo com um caráter assistencialista, sendo este reforçado pelo fato das Creches pertencerem e serem dirigidas por setores da Assistência e Promoção Social. O atendimento era oferecido por instituições públicas, filantrópicas, comunitárias, confessionais, que recebiam insuficientes subsídios financeiros dos órgãos governamentais. No geral, as Creches eram vistas como instituições que ofereciam um serviço precário, pois não apresentavam organização nem condições adequadas para a permanência das crianças por um longo período do dia; também dispunham de um quadro de funcionários com pouca escolaridade e nenhuma formação a respeito do desenvolvimento das crianças, em instalações físicas e espaços inadequados, sem programas planejados de educação ${ }^{2}$.

A partir da Constituição de 1988, do Estatuto da Criança e do Adolescente - ECA/1990 e da LDB/1996, a educação infantil é reconhecida como direito da criança, dever das famílias e dever do Estado, seja na Creche ou Pré-escola. E, com a passagem das Creches do setor da Assistência Social 
para a Educação se acentua a contraposição assistencialista versus educativo, sendo necessário, então, esclarecê-la, pois o suposto processo de superação inaugura outras relações, saberes e práticas no interior das instituições.

Para Kuhlmann Jr. (2000), a vinculação das Creches e Pré-escolas ao sistema educacional representa uma conquista em relação à superação de uma situação administrativa que mantinha um segmento de instituições educacionais específico para os pobres, no entanto as diferenças sociais permanecem, pois mesmo com a passagem para a educação, as Creches continuam a atender a mesma população.

Nessa perspectiva, o caráter assistencialista, anteriormente atribuído à educação infantil, denunciava uma visão assistencialista que acreditava na incapacidade das famílias da classe popular em educar os filhos; e, recentemente, no campo educacional, o atendimento em instituições representa a ideia de complementação à educação dada pelas famílias inseridas no atual contexto social. Nesse sentido, também se coloca outra concepção social sobre a educação das crianças pequenas e um outro olhar, socialmente construído ao longo do tempo, sobre a educação infantil, como responsabilidade da família e do Estado.

\section{A Pesquisa Realizada}

Considerando que a integração das Creches aos sistemas de ensino constitui um outro tratamento dado à educação infantil na faixa etária de 0 a 3 anos, bem como o avanço da discussão sobre a educação infantil nas últimas décadas, mas a gestão como uma temática ainda pouco explorada, visualizamos a necessidade de caracterizar e especificar a gestão ${ }^{3}$ nessas instituições a partir do estudo diagnóstico sobre a realidade das Creches de São Carlos- SP e assim caracterizar e analisar como se tem configurado essa gestão após sua passagem para a educação.

Para realizar o referido estudo combinou-se a pesquisa bibliográfica, a pesquisa documental e a pesquisa de campo, de forma a buscar elementos teóricos e empíricos para explicitar a especificidade da gestão da Creche após a passagem para a esfera da educação, no contexto atual.

Na pesquisa de campo realizada no final de 2004, realizaram-se entrevistas do tipo depoimentos para coleta de dados com as quatorze diretoras de Creches municipais da cidade de São Carlos, com vistas a caracterizar a gestão da Creche a partir de suas falas. A opção pela coleta de dados 
por meio de entrevista do tipo depoimento, uma variação do relato oral, foi devido a intenção de privilegiar apenas um recorte da vida das diretoras: sua trajetória profissional e, em especial, a escolha e atuação na educação infantil.

Considera-se que, através dos tempos, o relato oral sempre se constituiu uma fonte de conservação e transmissão de saber, relacionado a um passado muito recente como a experiência do dia a dia, aspecto muito importante para a pesquisa proposta.

[...] o relato oral se apresentava como técnica útil para registrar o que ainda não se cristalizara em documentação escrita, o não conservado, o que desapareceria se não fosse anotado; servia, pois, para captar o não explícito, quem sabe mesmo o indizível (QUEIROZ, 1988, p. 15).

A partir de uma perspectiva foucaultiana, as coisas ditas são sempre históricas e funcionam em práticas muito concretas, as quais dizem respeito à constituição de sujeitos de verdade, ou de como nos assujeitamos às verdades de nosso tempo, ou ainda de como buscamos discursos verdadeiros que nos constituam, no caso, de como as diretoras foram se constituindo enquanto gestoras de Creche. Analisar os relatos das entrevistadas significa extrair delas o enunciado de um discurso sobre a gestão da Creche sob o olhar da educação, ou seja, trazer a tona o que pensam e como buscam desenvolver um trabalho de gestão.

Para Foucault, os discursos são históricos, não só porque se constroem num certo tempo e lugar, mas porque têm uma positividade concreta, investem-se em práticas, em instituições, em um número infindável de técnicas e procedimentos que, em última análise, agem nos grupos sociais, nos indivíduos, sobretudo nos corpos (FISCHER, 2002, p. 55).

[...] sobre o corpo se encontra o estigma dos acontecimentos passados do mesmo modo que dele nascem os desejos, os desfalecimentos e os erros; nele também eles se atam e de repente se exprimem, mas nele também eles se desatam, entram em luta, se apagam uns aos outros e continuam seu insuperável conflito (FOUCAULT, 1979, p. 22).

Nesse sentido os relatos colhidos das entrevistadas sobre a trajetória profissional, pensamento e cotidiano do trabalho na educação infantil de o a 3 anos, expressam o conjunto de práticas que as constituem como gestoras 
da Creche sob a responsabilidade da área da educação.

\section{A Perspectiva Foucaultiana de análise}

Neste estudo propomos um outro olhar sobre a gestão escolar a partir de aportes da perspectiva foucaultiana ${ }^{4}$, analisando-a enquanto um campo de saber-poder.

A partir de pesquisas históricas e sua análise, Foucault mostra como foi possível formar domínios de saber a partir de práticas sociais, ou seja, descreve como essas práticas geram domínios de saber que fazem aparecer novos objetos, conceitos, técnicas e também fazem nascer formas novas de sujeitos e de sujeitos de conhecimento.

Ao analisar a história, os fatos, os acontecimentos, Foucault mostra como foi se constituindo um saber do homem, um saber que nasce das práticas sociais, das práticas sociais do controle e da vigilância, e que no século XIX fez nascer um tipo novo de sujeito do conhecimento. "[...] um sujeito que se constitui no interior mesmo da história, e que é a cada instante fundado e refundado pela história" (FOUCAULT, 2002, p. 10).

O conhecimento é inventado em um tempo e em um lugar, não está inscrito na natureza humana. Ele é sempre uma certa relação de estratégia em que o homem se encontra situado. "Só há conhecimento na medida em que, entre o homem e o que ele conhece se estabelece, se trama algo como uma luta singular, um tete-à-tete, um duelo" (FOUCAULT, 2002, p. 26).

A partir dessa ideia é que se pode pensar na formação de domínios de saber em torno de relações de força e de relações políticas na sociedade.

Para Foucault devemos compreender as relações de luta e de poder, a maneira pela qual as coisas e os homens entre si se odeiam, lutam, procuram dominar uns aos outros e querem exercer, uns sobre os outros, relações de poder, para compreendermos em que consiste o conhecimento. E que o conjunto das condições políticas e econômicas de existência é aquilo por meio do qual se formam os sujeitos de conhecimento e as relações de verdade.

Só pode haver certos tipos de sujeito de conhecimento, certas ordens de verdade, certos domínios de saber a partir de condiçooes políticas que são o solo em que se formam o sujeito, os domínios de saber e as relaçóes com a verdade. Só se desembaraçando destes grandes temas do sujeito do conhecimento, $[\ldots]$ poderemos fazer uma história de verdade (FOUCAULT, 2002, p. 27) 
Para o autor, o saber é uma construção histórica, que produz ele mesmo suas verdades, seus regimes de verdade que se instauram e se revelam nas práticas discursivas e não discursivas. É entendido como uma estratégia, um acontecimento vinculado ao poder, pois os saberes se engendram e se organizam para atender a uma vontade de poder. Nesse sentido, os saberes se constituem como base de uma vontade de poder e assim acabam funcionando como correias transmissoras do próprio poder a que servem.

A vontade de poder é intencional e se produz no jogo das práticas concretas e, dẹ acordo com as situações em que se estabelecem, buscam satisfazer interesses e acabam por conferir legitimidades.

O poder se manifesta como resultado da vontade que cada um tem de atuar sobre a ação alheia, como o resultado de uma vontade de potência, de modo a estruturar o campo possível da ação dos outros, ou seja, governálos. O poder só existe enquanto práticas que se manifestam, atuam, funcionam e se espalham, universal e capilarmente na rede de relações sociais em geral.

A origem dos saberes tem uma natureza essencialmente política, que se relaciona com a capacidade de cada um em interferir nas ações alheias. Essa capacidade se dá de formas diferenciais e estão presentes em todas as relações sociais que acontecem na rede social, sendo todas essas relações de poder.

Esse poder funciona como forças que atuam em cada um de nós, no nosso corpo, dividindo-nos, fracionando-nos, tanto internamente quanto em relação aos outros. É um poder microscópico que perpassa nosso corpo e todo o tecido social e é produtor de ideias, de saber e de moral.

O poder é uma ação sobre as ações e age de modo que aquele que se submete à sua ação o receba, aceite e tome como natural e necessário. Esse poder não emana de um centro, de uma instituição, de uma classe social, de uma organização ou do Estado, mas perpassa todos eles. Assim a dominação não seria de um grupo sobre outro ou de um sobre os outros, mas a partir das múltiplas formas de dominação que podem se exercer na sociedade em todas as direções e sentidos.

É nesta perspectiva de análise que apresentamos aspectos da gestão a partir das falas das diretoras participantes do estudo, destacando a produção de saberes e práticas na educação infantil na Creche sob o âmbito da educação. 
A gestão das instituições de educação infantil de o a 3 anos numa perspectiva foucaultiana

\section{A gestão das creches: a produção de saberes e o exercício de poder}

A passagem das Creches para a Educação e todos os discursos sobre a educação infantil (colocados pelos diversos meios) que a acompanham, parecem sugerir às diretoras a efetivação de outras práticas com relação à educação das crianças de o a 3 anos na Creche.

Essas outras práticas seriam necessárias em substituição as práticas existentes na Creche no tempo da Assistência, pois o que se pretendia era uma mudança sobre a visão da Creche e seu trabalho. Tratava-se, portanto, de uma forma de "revolução" no âmbito da educação infantil na Creche.

E aí eu conversei com as funcionárias e falei: olha gente, nós precisamos mudar muitas coisas. Preciso muito de vocês pra me ajudarem a mudar. Vocês querem mudar comigo? (...) E mudar uma visão da criança, mudar uma visão dos pais, foi difícil. Você incomoda, você cria conflitos entre as pessoas. Porque mudar, é difícil você mudar. Agora, você mudar através da visão de uma outra pessoa, é mais difícil ainda. Porque elas não tinham a visão de educação que eu tinha (Diretora $\mathrm{C}$ ).

Ao longo do tempo as práticas antigas e novas vão produzindo saberes sobre as crianças, sobre seu desenvolvimento, como lidar com elas, como é seu comportamento etc. $\mathrm{E}$ ao mesmo tempo que as práticas geram conhecimentos sobre a criança, vão produzindo as educadoras e a diretora no contexto da Creche sob a responsabilidade da Educação.

Então eu falei assim: não tem nada melhor do que eu estar aprendendo junto com elas, né? Então a parte nova para mim, eu procurava aquela educadora que estava alí... O 4 a 6 (anos) já era uma coisa que eu já estava acostumada. Aí fui conversando com elas, ficando lá, ia lá no berçário, ficava lá horas, observando, trabalhando junto, ajudava a dar comida, e através disso eu ia pegando. Um pouquinho aqui, um pouquinho ali... (Diretora A).

Foi tudo criado, tudo conhecido, criado experiências aqui dentro. E conhecendo. Aí eu comecei a procurar, fazer curso, capacitação, livros, apoio da própria secretaria, que dava capacitação. Fomos conhecer algumas creches privadas, particulares, mas conhecimento mesmo de funcionamento, não. Mas eu acho que é uma experiência que você aprende, a gente aprende praticando. Tudo que se aprende e põe na prática, a

REGAE, Santa Maria, v. 1, n. 2, jul./dez. 2009 
M. das G. Fernandes de Amorim dos Reis

gente vai tendo conhecimento (Diretora $\mathrm{J}$ ).

Essa produção de saberes sobre o fazer na Creche vai sendo mediada pelas diretoras, na medida em que elas foram chamadas com o propósito de caracterizar a Creche como um equipamento educativo, e para isso apostou-se que a diretora, ao ter formação pedagógica, daria conta do educar colocado como a inovação no tempo da Educação.

As novas práticas são percebidas a partir da especificidade do trabalho na Creche, a partir da orientação da diretora para as educadoras atuarem junto às crianças, uma vez que a diretora argumenta sobre a necessidade das relações de afetividade com as crianças; que as atividades sejam planejadas levando em conta os interesses e as necessidades das crianças, principalmente as de movimento; que o brincar seja orientado; que o brincar estimule a imaginação da criança; que o brincar ocorra a partir da interação com o educador; que a criança seja observada para se conhecer seu jeito e para saber lidar com ela; que as atividades sejam estimuladoras; que sejam propostas de modo a trabalhar os diferentes aspectos do desenvolvimento da criança; que a rotina seja diversificada com roda de conversa, com história, com dramatização; que se ocupe a criança, entre outras práticas enfatizadas durante os relatos.

Uma coisa assim que eu acho muito importante, que
eu falo para elas, é a parte afetiva, o conversar, o dar
carinho. Porque nós trabalhamos com uma faixa etária
que eles são muito carentes, o maior número de crian-
ças passa o dia todo sem os pais, então a gente tem
também que estar se pondo no lugar do pai, da mãe,
que não está ali naquele momento para dar um abra-
ço, dar um beijo, estar sentada ali brincando com eles
(Diretora A).
Eu falei: É muito importante a criança se expressar,
desenhar, deixar ela experimentar as coisas, mas an-
tes disso, vamos deixar ela brincar bastante. Não só
brincadeira livre, porque brincadeira muitas vezes é
deixar elas na sala, dar o brinquedo e deixa elas, mas é
a brincadeira orientada também (Diretora D).

Outras práticas também aparecem como necessárias para as questões de relacionamento, principalmente aquelas envolvendo os profissionais da Creche e os pais, pois no início eram bastante conflituosas, caracterizadas por situações de enfrentamento, de rudeza, grosseria, falta de respeito. Havia uma dificuldade de relacionamento maior entre as edu- 
cadoras e as mães no que se referia aos cuidados dedicados às crianças.

O relacionamento com os pais... minha nossa! Era assim bem distante, coisa distante. E achavam assim: pai não tem que por o bico aqui, que do portão para dentro ninguém tem que falar nada. Então eu comecei a fazer esse trabalho, de estar aproximando, e estou ainda, até hoje, trabalhando em cima disso (Diretora A).

Parece implícito que havia uma cobrança dos pais em relação às educadoras para tratarem bem os seus filhos; por parte das educadoras uma cobrança quanto à atenção, cuidados e educação dados pelas famílias às crianças; o fato de não trabalharem e estarem ocupando uma vaga que poderia ser dada para outra criança, com mãe trabalhadora, ou ainda a situação de abandono dos filhos na Creche. Inferência que pode estar relacionada a um aspecto marcante do assistencialismo, a prestação de um serviço como se fosse um favor.

[...] mas foi a minha intervenção. Porque... estou começando dando um exemplo. Eu trato todos com muita educação, com muito respeito, todas as funcionárias e todos os alunos. E todas as mães. Então, elas foram percebendo o modelo. Você é o modelo da creche. Modestamente falando, eu procurei ser modelo em todos esses anos. Modelo de bem tratar a mãe, de como tratar, aonde chegar (Diretora F).

A Creche na Educação, tendo a diretora como um agente de mudança, produz outras práticas no que se refere à forma de relacionamento e tratamento entre educadoras e pais, como resultado de um trabalho iniciado pela diretora, a partir de atitudes educativas com a comunidade. Fato que leva a caracterizar a Creche no tempo da Educação como um tempo de outras práticas a partir de outras relações entre os profissionais das unidades e a comunidade usuária, sempre com o objetivo de mudar a visão sobre o equipamento. Nesse aspecto parece ocorrer uma implantação da versão "cliente satisfeito", que tem que gostar do trabalho diferencial realizado e não mais com o serviço meramente prestado.

O que levou à mudança de tratamento de uma com a outra, foi o fato da minha funcionária respeitar primeiro a mãe. Eu achei que isso levou, lógico, algumas exageram, então você vai lá, 'olha mãe, não é assim, vocês estão... de lá da rampa solta a criança, vem aqui, conversa com a tia, pergunta se está tudo certo, se 
passou o dia bem, não é apenas pelo seu filho, às vezes a tia quer dar um recado prá você, não precisa 'ele comeu tudo?', 'a tia está ali, calma, não sei que...' Mas no mesmo ponto que começou primeiro a minha funcionária mudou a postura, aos poucos, certo, as mães também foram mudando (Diretora $\mathrm{N}$ )..

As diferentes práticas que se dão na Creche são sustentadas não só pelos saberes que as diretoras vão produzindo ao administrar a Creche, mas pelos saberes que trazem de sua formação e de outras experiências na área da educação.

Ao assumirem as Creches, elas partiram de um conhecimento que já dominavam sobre educação para iniciar um trabalho na educação infantil na Creche, e a partir de práticas de observação e análise do trabalho que se realizava cotidianamente, das mudanças que foram sendo introduzidas gradativamente, foi se constituindo um saber sobre a gestão da Creche, um saber sobre a educação de crianças de o a 3 anos, ao mesmo tempo que o próprio gestor também era produzido no interior dessas práticas. Tal como afirma Rodrigues (2001, p. 139), "no cruzamento do controle do espaço, do tempo e da vigilância sobre os indivíduos produz-se os saberes especializados".

No decorrer do tempo, ao concentrar muitas atribuições e responsabilidades, a diretora vai produzindo e dominando saberes específicos sobre a área de gestão da educação infantil na Creche, visto que começou a existir na estrutura da unidade ocupando um lugar na hierarquia com a função específica de empreender mudanças.

A diretora ao ser fixada na Creche elabora formas de envolver as educadoras, formas de estabelecer, de orientar, de acompanhar, de cobrar, de redirecionar e até de fazer junto o trabalho que deve ser realizado diariamente. Todas essas são relações de poder exercidas sobre os outros que visam produzir, construir o trabalho da Creche no tempo da Educação.

\footnotetext{
Antes você tinha assim uma dificuldade às vezes de estar conversando com funcionário, houve... quando ... hoje, quando nós viemos pra cá, nós já viemos com aquela questão de ouvir, trabalhar junto, fazer a coisa andar junto, e sem eles não adianta eu vim aqui com a maior das boas intenções que a coisa não anda. E coisas que... antigamente, não se tinha isso. Não tinha mesmo. Às vezes não era por culpa dos diretores, é porque realmente às vezes não fazia parte da filosofia pedagógica de direção e de gestão (Diretora $\mathrm{N}$ ).
} 
No início, não havia entre as diretoras uma clareza sobre o que fazer, portanto as observações e a análise sobre o que acontecia na Creche funcionaram como a principal fonte de conhecimento, ou seja, ao mesmo tempo em que iam administrando a Creche, iam aprendendo a administrar, iam tentando atender à expectativa de educar que se tinha desta instituição agora no âmbito da Educação.

\begin{abstract}
Mas era técnica de observação. Eu sempre gosto. Como você falou, observar, analisar e ver se realmente está correto, está funcionando. E se está certo aquilo.... e experimentar. Se ver que não adiantou, volta. Eu acho que a gente consegue $\operatorname{sim}$ (Diretora $\mathrm{N}$ ).
\end{abstract}

$\mathrm{Na}$ medida em que as diretoras vão dominando um conjunto de conhecimentos sobre o funcionamento da Creche e sobre o trabalho realizado na perspectiva do educar, vão mudando práticas, produzindo outras e avaliando / visualizando outras possibilidades para implementar o atendimento na Creche. Estas manifestações foram de várias ordens, tais como: contratação de outros profissiọnais, como um enfermeiro, um médico, um psiçólogo, um assistente social, um terapeuta ocupacional, um professor de educação física, um auxiliar administrativo, um coordenador pedagógico; substituição periódica de brinquedos e materiais didático-pedagógicos, pois ao longo do tempo vão estragando e se perdendo com a manipulação.

Nas Creches municipais de São Carlos, as mudanças foram ocorrendo gradualmente, sempre a partir do olhar e iniciativa da diretora (mas também impulsionada pela Secretaria Municipal de Educação) a partir de como ela estava entendendo como seria a Creche na educação e quais as mudanças necessárias para atender a ideia de inovação/reorganização. As mudanças começaram por reformas e adaptações das instalações, de forma a adequar o ambiente à faixa etária atendida.

Pintei a escola inteirinha. Reformei a cozinha, tudo com suprimentos. Devagarzinho, deixei assim uma escola alegre, começamos a decorar a escola, começamos a colocar as pessoas no lugar. Então, dizer, hoje é uma outra creche. Em todos os sentidos. A cabeça delas está assim: elas já assimilaram que isso aqui é equipamento pedagógico. Já assimilaram (Diretora F).

Deste ponto de vista, atribui-se grande importância ao papel da diretora na Creche, sendo muito frequente nos relatos as ideias que evidenciam 
a necessidade da realização de um conjunto de atividades referentes a: fazer a instituição funcionar; corrigir, estabelecer, cobrar, interferir, orientar as funcionárias; organizar tempo, espaço, rotina, documentos diversos; promover e facilitar um novo trabalho; providenciar os meios, os recursos para as mudanças e a realização do trabalho; mudar a visão dos pais, da comunidade, das funcionárias; enfim, empreender todas as mudanças necessárias desde a adequação da estrutura física para a faixa etária atendida até a organização do trabalho.

Mas pelo menos a minha intenção é essa, porque se eu não fizesse isso, eu tenho certeza, eu não teria mudado nada aqui dentro. Eu não teria mudado a forma delas tratarem as mães, eu não teria mudado a forma delas tratarem as crianças, porque a mudança que eu quero não depende de mim obrigar elas. Tem que ser delas, elas têm que mudar. Tem que ser um tratamento de dentro delas. E cada um tem seu tempo (Diretora $\mathrm{N}$ ).

No cotidiano a diretora realiza diferentes atividades, de planejamento, de execução, de acompanhamento e verificação. Grande parte dessas atividades é caracterizada como tarefas burocráticas e administrativas. Percebemos que ora aspectos administrativos e pedagógicos se separam, ora não, quando na verdade um dá suporte para o outro.

O conjunto dessas atividades que se desenvolvem no cotidiano da Creche pode ser entendido como relações de força e poder no interior da instituição, na medida em que as diretoras orientam sobre o que fazer, como fazer, por que fazer, na medida em que introduzem mudanças, na medida em que há resistência de outros a essas orientações e também há a resistência da própria diretora com relação ao trabalho desenvolvido pelas funcionárias da Creche até então. A diretora vai exercendo micropoderes sobre as pessoas e, consequentemente, sobre o trabalho delas.

[...] eu tive que ir arrumando uma série de coisas e explicando o porque. Porque que eu ia abaixar o gancho da mochila? Porque que eu tinha que abaixar o lixo? Então eu tive que explicar. Agora, eu achei estranho porque explicar para elas naquele momento, sendo que as creches já tinham passado para a educação em 99? Então eu não conseguia entender esse meio de campo (Diretora G).

Tem que estar vendo, não só a criança, como a gente faz, até com a convivência. Aliás, eu acho que isso é função de direção. Você tem que saber o que facilita a vida da sua cozinheira, o que facilita a vida da lava- 
A gestão das instituições de educação infantil de o a 3 anos numa perspectiva foucaultiana

deira, você observa que a pessoa está trabalhando com certa dificuldade, com determinado aparelho, aquilo não está dando certo. Eu gosto às vezes de dar uma passada, de dar uma olhada, eu observo. Eu observo às vezes criança no andar, postura que a criança está... (Diretora N).

A entrada da diretora na Creche teve um papel essencial, pois ela impulsionou a "reforma", não com papel salvacionista, mas ao mesmo tempo libertador dos pobres, dado a ideia de que as crianças da Creche precisavam ter o direito de ser criança, de ter coisas de criança.

\begin{abstract}
Uma coisa que me chocou muito foi o fato de eu ver aquelas crianças 10 horas por dia dentro de uma sala fechada, sem um brinquedo, sem uma atividade assim... Porque elas brincavam com sapatos velhos, com roupas velhas, restos de bazar que se fazia nas creches até então. (...) Você via aquelas crianças ali, um grupo de 40 crianças, enroladas naquelas roupas velhas, naqueles sapatos, tentando ser criança. Quer dizer, num espaço que não era para criança, com condições que não eram de criança, mas ali tinha o sonho da criança (Diretora C).
\end{abstract}

Percebe-se ainda uma dicotomia entre gestão e educação, na medida em que se separam atividades administrativas e atividades pedagógicas na atuação, embora essas atividades se articulem no cotidiano e ambas configurem a gestão do equipamento. Parece não estar claro que as atividades administrativas são meios para que as pedagógicas se efetivem, como indicado no relato abaixo:

Eu vejo hoje as meninas, elas fazem planejamento, sabe, tem o trabalho pedagógico, sim, eu falo em relação elas, os projetos que elas estão fazendo, nossa, é um encanto, mas assim eu acabo correndo atrás. Por exemplo, se elas estão precisando de alguma coisa pra concluir o trabalho delas, eu trago, eu vou, mas não tenho tempo de ficar assim mais direto vendo isso. Então eu acompanho... Eu sei o que está acontecendo, se elas precisam de qualquer coisa, que eu possa estar ajudando, você faz assim, mas de você assim, de passar alguma coisa mais assim, fica mais devendo, por conta das outras coisas (Diretora $\mathrm{H}$ ).

No cotidiano da Creche, o papel da diretora apresenta-se como centralizador, ora como líder, ora como mediadora, ora como intermediária. Tal ideia se faz presente pelas diferentes relações estabelecidas entre a 
diretora e os outros segmentos da Creche, ou seja, a diretora em relação às educadoras e/ou ao trabalho realizado e/ou aos pais, e às educadoras em relação aos pais. Trata-se basicamente das orientações, acompanhamento e intervenção.

Daí fica pra você resolver tudo, a parte pedagógica, você tem que estar preparando os funcionários, tem que estar observando tudo, observando as crianças, atuando e interagindo em tudo, na cozinha, na alimentação, então não é fácil. Então um grupo de atividades na verdade. E se você não estiver bem preparada na verdade, mesmo emocionalmente, você cai um pouquinho. Então você tem que estar ligada com tudo, e você tem que estar melhor preparada do que todo mundo (Diretora L).

Onde eu acho que tem que intervir? A maioria das vezes é na parte da disciplina. Aí vem o papel do diretor de estar chamando, porque enquanto colegas de trabalho, uma não se vê com autoridade suficiente pra chegar e falar "Olha, isso que você está fazendo está errado". Apesar da gente ver, da gente perceber que elas se relacionam muito bem entre elas. Tipo assim: "Olha, tá sobrando muito pra mim, isso não é justo". Então, no caso, quando chega até aqui, já fugiu do controle delas. Aí que eu vou intervir. Então é mais um papel de intervenção do que de autoritarismo (Diretora $\mathrm{O}$ ).

No interior da instituição, a diretora vai tanto estabelecer como fazer parte de um conjunto de relações de poder, que perpassa tanto as relações entre ela e as educadoras, como entre ela e os pais. Esse poder deve ser visto na sua positividade, na medida em que é produtor de conhecimento e de outras práticas no interior da Creche, a partir da ação da diretora junto aos outros.

Às vezes, quando elas chegam, elas chegam agressivas. Porque elas também passam experiências amargas. Elas também são maltratadas em alguns lugares. Não sei onde, mas esse povo é muito sofrido. Eles são maltratados em muitos lugares, então, quando chega aqui, que a gente cobre eles de atenção, que é nossa obrigação, como pessoa e como educador, elas te dão o feedback na hora. Não tem como uma pessoa te agredir, à medida que você está sendo educada e leal com ela, olhando nos olhos (Diretora F).

Esse poder geralmente é associado ao cargo de diretora e suas atribuições, mas de outro ponto de vista significa colocar em funcionamento o 
desejo de governar as ações alheias numa perspectiva de mudanças. No caso, governar as coisas e as pessoas na Creche sob o olhar da Educação. Ocorre que, juntamente com a entrada da diretora na Creche, também se estabeleceu qual seria sua função: mudar, inovar, substituir, tanto pensamentos como práticas ao cuidar e educar das crianças pequeninas. Desse ponto de vista, é que parece se dar uma espécie de "revolução", a qual por sua vez parece trazer uma forma de economia, pois visa produzir pobres de maneira mais eficaz.

No dia a dia, ao desempenhar sua função, a diretora acaba tendo um tipo de poder judiciário, uma vez que orienta, que regulamenta, que prescreve, que julga, que sanciona um conjunto de situações e ações dentro da Creche. De diferentes formas, a diretora da Creche acaba tendo um papel disciplinador das ações dos outros e do trabalho, na medida em que visa governar e controlar tudo que acontece na instituição.

\footnotetext{
Precisei chegar com uma régua na hora do almoço, bater a reguinha: deixa eu ver a sua mãozinha. Ah, que mão suja! A tia não lavou a sua mão? Precisei chegar'e fazer isso. Aí a tia: é, não deu tempo. Então eu precisei... você vê o tipo de cobrança que eu precisei fazer. Que elas ficassem com medo...É, estava verificando. Então eu precisei colocar um certo medo, que eu fosse lá no dia seguinte e olhasse a mão delas, das crianças, se estavam lavadas ou não. Pra poder criar o hábito. Tanto nas crianças quanto nelas, nas profissionais. Então, você veja bem, não lavar a mão das crianças pra comer, foi um retrocesso pior do que em 99. Então existe essa função pedagógica (Diretora $\mathrm{G}$ ).
}

No jogo das relações que se dão no cotidiano, as relações de poder vão produzindo saberes sobre os indivíduos e sobre o trabalho deles, e estes conhecimentos vão se aprimoramento e contribuindo para a produção de novas formas de controle e governo. Essas relações de poder e força devem ser entendidas como produtoras de novas relações que se desejava estabelecer na Creche agora no âmbito da Educação.

O papel da diretora se associa então à ideia de/ou a necessidade de se estabelecer uma outra ordem na Creche, que visava colocar as coisas sob outro ponto de vista, que promovesse o educativo.

Desse ponto de vista, ganha importância a dimensão pedagógica da função da diretora na Creche, ou seja, a partir da figura da diretora, que detinha uma determinada formação pedagógica, se iniciaria por meio de orientações mais especificas a questão do educar. Para muitas, essa seria a 
razão da existência da diretora na Creche.

Diminuímos as crianças, melhoramos o atendimento, a qualidade, que era a minha proposta, acabou aquele trato que era dado, que não era um cuidar, era um trato, introduzimos o cuidar, inserimos o educar junto, de repente, as verbas.... (...) Então elas têm o material que elas querem, elas têm de tudo, tudo eu exponho aqui, é tudo muito aberto, muito democrático. Então inserimos o educar. Com qualidade? Com qualidade. Com falhas? Com falhas. Mas ele está aqui dentro, ele está presente (Diretora M).

A diretora da Creche tem sido vista então como aquela responsável por inserir a ideia do educar, por organizar, orientar e interferir na busca e efetivação de um trabalho pedagógico.

E aí o que há de novo, de atividades, de jogos, de livros,
a gente tem trazido, apresenta pra elas, ajuda a fazer,
elas se organizam em grupo, desenvolvem o material,
alguma coisa assim, e a gente vai orientando, 'Olha,
isso dá certo, isso não dá, deu certo, não deu'. A gente
vai passando pra ver (Diretora L).

Então quando a gente faz a reunião pedagógica, que a gente leva livros, que a gente propõe um projeto, que o diretor até elabora dinâmicas, que envolve todo mundo, então esse está sendo o papel do diretor. Interagir o grupo, apresentar materiais, pra que esses profissionais desenvolvam, estejam acessiveis para as pessoas. Então hoje as educadoras lêem, elas lêem textos, elas participam de reuniões, elas participam de dinâmicas. Então eu atribuo o papel do diretor a isso: levar pra elas tudo que seja acessível, para elas se enriquecerem e poderem voltar isso pra criança (Diretora $\mathrm{O}$ ).

A ênfase no educar, a busca de organizar um trabalho pedagógico a partir da orientação da diretora junto às educadoras, foram ideias bastante ressaltadas pelas entrevistadas, na medida em que os relatos indicam que no cotidiano a diretora da Creche realiza reuniões para estudo e discussão sobre o trabalho; reuniões de planejamento; momentos de orientação e acompanhamento; elaboração e retorno dos registros sobre o trabalho e sobre a criança.

Então, na primeira reunião pedagógica eu até montei um esqueminha para que elas pudessem acompanhar o meu raciocínio também. Então a primeira reunião pedagógica foi baseada em quê? No livro "Creches, cri- 
ança e cia.", o capítulo 7 que diz: partir de onde? Qual a necessidade de se planejar uma atividade? Qual a importância do planejamento, qual a importância de se identificar o que a criança precisa, o que a sua turma está precisando, naquele momento, o porquê fazer isso (Diretora G).

Ao mesmo tempo em que muitas das entrevistadas ressaltaram a importância ou a necessidade de organização e efetivação do trabalho pedagógico das educadoras junto às crianças para atender a ideia do educar, também indicaram as dificuldades em relação à realização dessa prática, tais como: a quantidade de atividades administrativas que realizam; a falta de tempo e de uma orientação mais sistematizada a partir do acompanhamento de uma coordenadora pedagógica; a resistência das pajens quanto ao educar pelo fato de terem pouca escolaridade e nenhuma formação na área de educação; a formação superficial das professoras; a própria estrutura organizacional da Creche que funciona 10 horas por dia com funcionários de 8 horas; a não previsão de reuniões periódicas dentro da jornada de trabalho para estudo, discussão e planejamento; a inexistência de funcionários para cobrir as faltas que ocorrem. Ou seja, esta "empresa" que se quer "moderna" ainda mantém relações estreitas com outra ordem, a educativa.

\footnotetext{
Por exemplo, uma das coisas que eu percebo da parte pedagógica, fica muito assim nessa questão de você não estar com o grupo todo, no dia a dia, e acaba ficando um pouco prejudicado. E também essa questão da troca, do cuidado com a criança. Por exemplo, se uma professora falta, e eu não tenho ninguém pra pôr, eu tenho que misturar as turmas (Diretora B).
}

As dificuldades apontadas demonstram claramente que a estrutura organizacional da Creche ainda não mudou, permanecendo a mesma tal como veio da Assistência Social, sendo um aspecto bastante ressaltado pelos profissionais que atuam nas unidades e que tem contribuído para a ideia de que as Creches passaram para a área da Educação há mais de 5 anos, mas ainda não passaram a ter uma estrutura como organização escolar, visto que não têm recesso nos meses de julho e dezembro, não têm formalizado um espaço/tempo para trabalho pedagógico na unidade e também na jornada de trabalho do professor ou educador.

Inicialmente, as funcionárias que vieram da Assistência apresen- 
taram resistência com relação ao educar. Posteriormente, com a entrada de professoras com formação pedagógica também ocorreu uma outra forma de resistência, agora com relação ao cuidar, aos cuidados de higiene, alimentação e descanso das crianças.

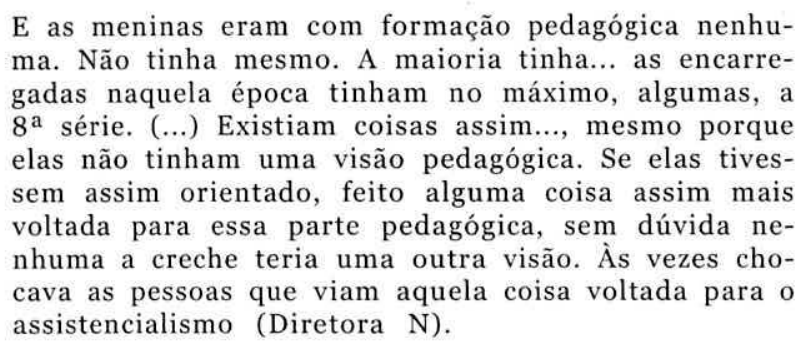

Cabe destacar que no tempo da Educação, o fato de outros profissionais começarem a fazer parte do quadro funcional das Creches é visto como inovação: o diretor/gestor de escola apresenta Licenciatura em Pedagogia com habilitação em Administração Escolar em substituição à assistente social e à encarregada; e professores, com no mínimo o curso de Magistério na modalidade Normal de Nível Médio, que foram contratados, na medida em que surgia uma vaga anteriormente ocupada por pajens. Entretanto, o equipamento permanecia com a mesma estrutura.

A atuação de pajens e professoras na mesma unidade gerou algumas tensões no dia a dia a Creche que se relacionavam com as atribuições de uma e de outra, ou seja, de ambas as partes havia a ideia de que as pajens realizariam os cuidados: higiene, alimentação, descanso das crianças, e as professoras se dedicariam às atividades educativas.

\footnotetext{
Então o professor veio achando que ele ia fazer o que ele faz na pré-escola. E que a pajem iria auxiliá-lo. E não foi assim. Porque a pajem hoje, como educadora, e ela já incorporou o educadora, ela não se vê mais como pajem, ela assumiu a sala dela e o professor a dele. Então a parte pedagógica às vezes a pajem se espelhava no professor. Ou às vezes até esperava do professor. Então houve essa resistência, porém, foi também positivo (Diretora O).
}

Tal situação pode ter sido gerada em face do discurso de educar como sendo a diferença oferecida pela Creche no tempo da Educação. Ou seja, o educar estava sendo visto como uma realização a partir de um trabalho pedagógico que as professoras supostamente dominariam devido à forma- 
ção na área de educação (saber técnico) que a maioria das pajens não tinha no momento.

O educar estava, muito provavelmente, sendo caracterizado por atividades/ações que deviam ser planejadas, previstas, baseadas em conhecimento já produzido sobre o desenvolvimento das crianças, por situações voltadas para um processo de ensino/aprendizagem intencional e sistematizado, o que reforça a ideia de escolarização da criança na Creche.

Ressaltamos que a partir dessa ideia corre-se o risco de descaracterizar a função de cuidar e educar tanto da Creche como do educador, seja pajem ou professora, como se as ações de cuidado não educassem as crianças, como ações que não se encontrassem na prática, o que, segundo as entrevistadas, seria bem o oposto:

Hoje não, hoje o que é educar? A criança vai comer, ela tem que ser educada, ela vai dormir, ela tem que ser educada, a criança vai brincar, ela tem que ser educada, a criança vai trocar de roupa, ela tem que ser educada. Tudo de maneira agradável, sem aquele autoritarismo. Ela está ali inteirando o tempo com a criança, então é educar mesmo, como se come, como se dorme. Coisa que se a criança chega em casa, ela vai dormir, ela não teve mais nada durante o dia. Então fica outra creche. Então educa-se nas brincadeiras, no faz de conta, na alimentação, na parte de higiene (Diretora $\mathrm{L}$ ).

A partir dos relatos sobre a realidade de São Carlos, podemos afirmar que boa parte das dificuldades percebidas para atender ao aspecto de educar estava relacionada à formação e à própria visão sobre a Creche e o trabalho a ser desenvolvido, das pajens e professoras, uma vez que as primeiras não tinham uma formação pedagógica e as segundas apresentavam uma formação superficial.

Porque o professor também demorou pra se conscientizar que a creche não era mais assistencial. E a própria formação do professor não foi... Pra você ver como a política não era direcionada pra criança de o a 3 anos, que até pouco tempo atrás, a formação também do professor não era de o a 3 anos (Diretora $O$ ).

A questão da formação nos remete aos cursos de formação de professores, na medida em que as entrevistadas afirmam que os cursos existentes não estão formando professores de educação infantil para atuar nas Creches para a faixa etária de o a 3 anos. Os cursos de formação de professores 
para educação infantil devem ser revistos para que tratem da realidade e do trabalho realizado nas Creches.

De qualquer forma, a entrada de novos profissionais - com determinada formação na área educacional, como a diretora e as professoras parece ganhar bastante destaque no que se refere à implantação e implementação do novo na Creche, uma vez que algumas entrevistadas afirmaram que a Creche só inovaria no processo de educar a partir da existência de professores que tivessem uma consistente formação na área de educação infantil. Fato que nos leva a considerar que a nova organização do trabalho denominado educativo/pedagógico na Creche encontra-se em processo de construção.

O que é a creche? O que fazer a mais além do cuidar, como fazer? É colocar ela num contexto de pré-escola. Mas eu acho que nós não vamos encontrar: Vamos fazer agora a minha creche, enquanto você não tiver esse pessoal especializado. Pelo menos professor. No mínimo professor. Porque a identidade da creche, para mim esse equipamento pedagógico tem que ser abrangente. $O$ educar no sentido amplo, e o cuidar. $O$ cuidar se cuida. E ainda tem uns resquícios do assistencialismo. Mas esse educar no sentido amplo nós estamos conseguindo, mas é só com educadores, com a formação específica, que você vai dar esse aspecto pedagógico pleno para a creche (Diretora F).

[...] porque eu acho que o que está faltando um pouco é de oficinas mais práticas, que elas façam coisas. (...) As nossas educadoras, tem umas de $1^{\mathrm{a}}$ a $4^{\mathrm{a}}$, umas de $1^{\mathrm{a}}$ a $8^{\mathrm{a}}$, e duas professoras. Com uma formação muito precária. Muito precária. Os cursos que são dados, os primeiros, foram longos demais, e com termos que não chegaram até elas. Elas iam, dormiam, não entendiam, chegava aqui, nunca mais tocava no assunto. Os cursos que a gente teve até agora, eu vou falar o que é que eu acho, certo? Houve muito boa vontade da secretaria de proporcionar, mas não se aproveitou muito não. Porque tem uma outra coisa: quem vai nos cursos mais simples, que vem de acordo com o que elas precisam e numa linguagem acessível, as que vão, elas se fecham em copas, elas não socializam. Porque nós nem tínhamos tempo para a socialização (Diretora F).

Entretanto, só a formação acadêmica inicial não basta, mas um conjunto de conhecimentos também proporcionados pela vivência e experiência na educação infantil, na medida em que configuram também as condições produtoras de saberes e de profissionais. Então, além da necessida- 
de de repensar os cursos de formação dos professores para atuarem nas Creches, também é necessário a continuidade e o aperfeiçoamento das formas de capacitação das educadoras, das pajens e professoras já existentes nas unidades, pois os cursos oferecidos ora correspondem às expectativas dos participantes, ora não.

\section{Considerações Finais}

Em síntese, o campo de saber da gestão escolar que foi se constituindo e se desenvolvendo ao longo do tempo, engendrou um saber a partir das relações de forças que se dão no âmbito escolar, ou seja, foi produzindo saberes e sendo produzido ao coordenar e controlar as ações dos outros, atendendo a uma vontade de poder, a qual se relaciona também com o exercício de poder das instâncias governamentais da qual serve com um agente.

No jogo de forças no interior da escola, o exercício do poder do gestor por meio dos saberes que detém funciona como uma forma de manutenção do exercício do poder e controle sobre os indivíduos, não a partir de sua individualidade como sujeito, mas com o seu caráter civilizatório investido na figura de diretor. E são essas mesmas relações de força, de poder entre os homens e as coisas no cotidiano da escola que produzem o gestor e o colocam com "o poder da governabilidade" na escola.

No caso da gestão na educação infantil entendemos que é a partir do conjunto de forças que se travam no interior desta instituição, na sua complexidade e singularidade, que se produz um saber específico que vai produzindo o gestor da educação infantil.

$\mathrm{O}$ atributo de complexidade se relaciona com a ideia de que este tipo de instituição é atravessado por uma série de outros discursos e práticas sobre a criança e a infância, a educação de serviços marcada pela história de assistencialismo, o atendimento como direito, as políticas públicas, a relação com a comunidade, o desenvolvimento e aprendizagem infantil. É singular no sentido de que o gestor da educação infantil só é produzido neste contexto, neste entrelaçamento de saberes e poderes que se dão no cotidiano.

O que queremos enfatizar é que essa passagem das Creches da Assistência para a Educação representa um marco, um outro momento que gerou outros discursos e se entrelaçou com eles, dando origem às práticas específicas de gestão, agora no âmbito das verdades produzidas no campo 
da educação. E é só a partir desse momento que se pode caracterizar a gestão da Creche.

A passagem das Creches para a educação marca o início da produção de outros discursos e outras práticas relacionando a gestão da educação de crianças pequenas a um saber-poder, que vai sendo produzido e produzindo o gestor da Creche.

Neste raciocínio a gestão da educação infantil nas Creches engloba um conjunto de relações de força e de poder que ocorrem no interior dessas instituições, entre gestor, funcionários, crianças, pais e ainda do macropoder político (Secretaria Municipal de Educação). É o conjunto dessas relações que geram saberes sobre gestão da educação infantil, sobre a educação da criança pequena, sobre políticas públicas, sobre qualidade de educação. Enfim configura, produz um saber-poder, um poder-saber, que ao mesmo tempo que é específico é também totalizante, na medida em que vai fazendo parte do discurso e da prática sobre a gestão da educação infantil, vai sendo aceito, transmitido como necessário e natural para a efetivação do trabalho.

\title{
Notas:
}

1 Nova organização dada por duas leis que alteram artigos da LDB, a saber: Lei ${ }^{\circ}$ 11.114/05 dispondo que a matrícula no ensino fundamental passa a ser obrigatória aos seis anos de idade, e pela Lei $\mathrm{n}^{\circ} 11.274 / 06$, mantendo a matrícula obrigatória aos seis anos e ampliando a duração do ensino fundamental para nove anos (ABREU, 2006).

2 Quadro apresentado pelo Plano Nacional de Educação, Lei no 10.172, de 9 de janeiro de 2001.(BRASIL, 2001).

3 Utilizamos o termo Gestão como forma de administração atualmente discutida para as instituições escolares, que pressupõe a participação dos vários segmentos da comunidade escolar na tomada de decisão no cotidiano da escola.

4 Utilizam-se os termos perspectivas ou teorizações foucaultianas, porque o próprio Michel Foucault não considerava seu pensamento e sua forma de análise como uma teoria (VEIGA-NETO, 2003, p. 23).

\section{Referências}

ABREU, M. Mudanças na educação. Nova lei altera o ingresso e a permanência no Ensino Fundamental. Revista do Professor, Porto Alegre, v. 22, n. 87, p. 42-43, jul./set., 2006.

\author{
ABRAMOWICZ, A. et. al. Trabalhando a diferença na educação \\ infantil. São Paulo: Moderna, 2006.
}

BRASIL. Lei Federal n. 10.172/01 - Plano Nacional da Educação. 
Senado Federal, 2001.

BRASIL. Ministério da Educação. A Constituição de 1988 e a educação de crianças pequenas. São Paulo: FDE, 1989.

BRASIL. Ministério da Justiça. Estatuto da Criança e do Adolescente. Lei n. 8.068, de 13/07/1990.

BRASIL. Ministério da Educação. Lei 9.394, de 20/12/1996, Estabelece as Diretrizes e Bases da Educação Nacional. Diário Oficial da União, v.84, n.248, 23 dez. 1996.

FISCHER, R. M. B. A paixão de trabalhar com Foucault. In: COSTA, M. V. (Org.). Caminhos investigativos: novos olhares na pesquisa em Educação. Rio de Janeiro: DP\&A, 2002. p. 39-60.

FOUCAULT, M. Microfísica do poder. Organização e tradução de Roberto Machado. Rio de Janeiro: Graal, 1979.

FOUCAULT, M. A verdade e as formas jurídicas. Tradução de Roberto Cabral de Melo Machado e Eduardo Jardim Morais. Rio de Janeiro: NAU, 2002.

KUHLMANN, M. Educação infantil e currículo. In: FARIA, A. L. G. de; PALHARES, M. S. (Org.). Educação infantil pós LDB: rumos e desafios. 2. ed. São Carlos, SP: UFSCar, 2000. p. 51-65.

QUEIROZ, M. I. P. de. Relatos orais: do indizível ao dizível. In: VON SIMSON, O. R. de M. (Org.). Experimentos com histórias de vida: Itália-Brasil. São Paulo: Vértice, 1988. p. 14-43.

RODRIGUES, L. A. Nômades, bárbaros e guerreiros: os educadores e educadoras das ruas e das instituições para menores. 2001. $235 \mathrm{f}$. Dissertação (Mestrado em Educação). Universidade Federal de São Carlos. São Carlos, SP, 2001.

VEIGA-NETO, A. Foucault \& a educação. Belo Horizonte: Autêntica, 2003. (Pensadores \& Educação, 4).

\footnotetext{
Maria das Graças Fernandes de Amorim dos Reis Doutora em Educação - UFSCar; Professora Adjunta - UFMS/CPNV E-mail para correspondência: gmgrg@ig.com.br
} 